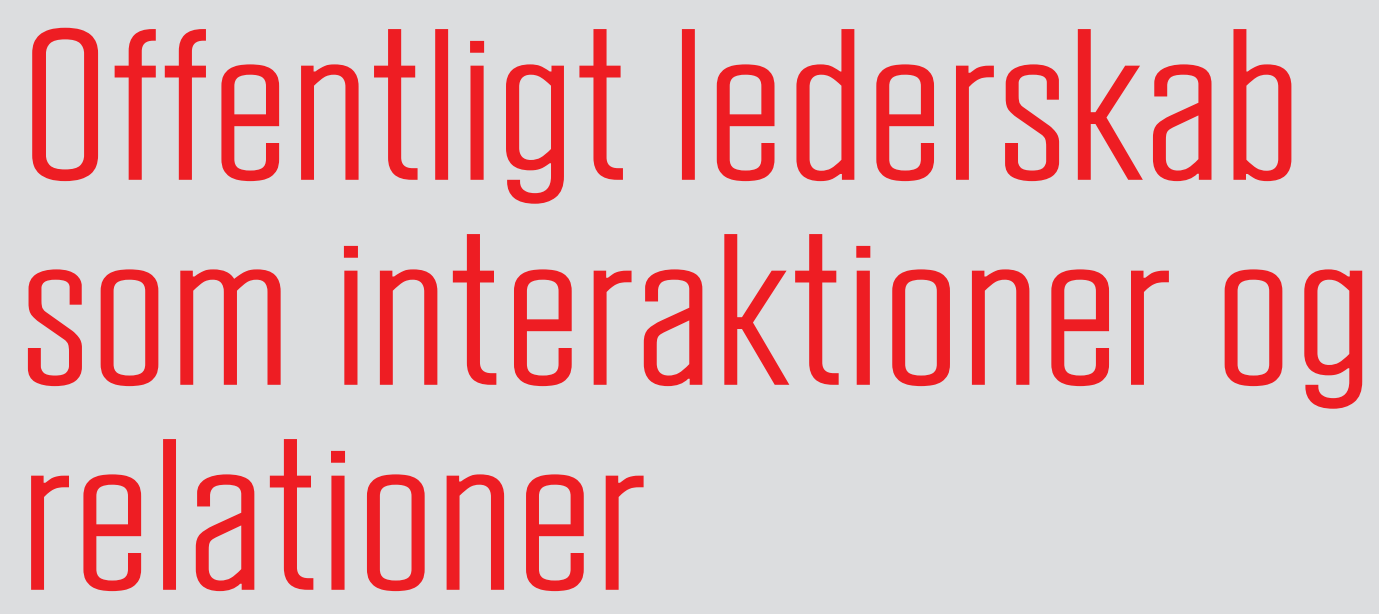

ROMANTISERING AF LEDERSKAB • DELT LEDERSKAB RELATIONEL LEDERSKABSTEORI - TRANSFORMATIVT LEDERSKAB • KOMPLEKSE ORGANISATIONER

Magnus Larsson og 


\section{Offentligt lederskab som interaktioner og relationer}

\section{ROMANTISERING AF LEDERSKAB • DELT LEDERSKAB RELATIONEL LEDERSKABSTEORI • TRANSFORMATIVT LEDERSKAB • KOMPLEKSE ORGANISATIONER}

Interessen for ledelse, lederskab og lederskabsteori i offentlig sektor er steget betydeligt de seneste 20 år. I artiklen argumenteres fo, at den måde vi tænker om og taler om lederskab, kan have stor betydning for hvordan det kan udøves i praksis. Lederskab er en lille, men vigtig del af det at være leder, og handler dybest set om at skabe indflydelse, bevægelse og om at mobilisere mennesker. I såvel forskningslitteraturen som i mere populære tekster bliver begrebet lederskab brugt i mange forskellige betydninger. Oftest handler det dog om en enkelt person, det vil sige lederen. Ikke mindst i offentlige organisationer, som typisk tilbyder en kompleks og mangfoldig kontekst, er værdien af fokus på en enkeltperson dog begrænset. I stedet kan vi søge inspiration i den del af lederskabsforskningen, som mere fokuserer på elementer som delt lederskab og som lægger vægt på relationer og interaktioner, og som opfatter lederskab som en proces. I denne artikel gennemgår vi nogle af de centrale teoretiske retninger indenfor feltet, og illustrerer brugbarheden i at italesætte lederskab mere i termer af interaktioner og relationer, end i termer af personer. 


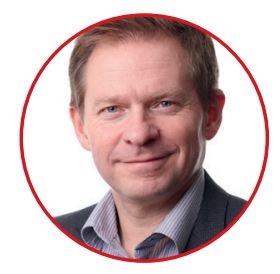

Magnus Larsson

Magnus Larsson har en $\mathrm{PhD}$ i psykologi fra Lunds universitet, Sverige, og arbejder som lektor på Institut for organisation, CBS. Magnus har i mange år forsket om leadership og ledelsesudvikling, og var blandt andet projektleder for et forskningsprojekt om ledelsesudvikling i offentlig sektor 2014-2018. Han har blandt andet publiceret i Human Relations, Leadership, International Journal of Business Communication. Han underviser primært om lederskab, og arbejder også til tider som konsulent med ledelsesudvikling og ledelsesteamudvikling i såvel Sverige som i Danmark.

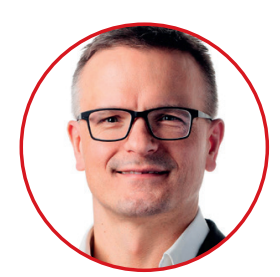

\section{Frank Meier}

Frank Meier Frank Meier er cand.scient.pol. fra Københavns Universitet og aktuelt Ph.D.-studerende på Institut for Organisation, CBS. Frank har i mange år undervist i ledelse på CBSs masteruddannelser, særligt MPG. Franks forskning handler om hvordan ledere bliver udviklet på lederuddannelsesprogrammer og bidrag fra hans forskningsprojekt kan findes i tidsskriftet Human Relations. Frank er blandt andet optaget af hvordan de studerendes egen ledelsespraksis på den ene side bliver inddraget $\mathrm{i}$ ledelsesuddannelse og hvordan den praksis på den anden side bliver påvirket af uddannelsen. 


\section{Indledning}

Lederskabsforskningen har igennem mange år produceret meget og til tider modsætningsfuld viden. Vi vil her i artiklen på den ene side søge at bidrage med et overblik over den viden og samtidig prøve at forblive loyale mod dens modsætningsfyldte og konfliktende karakter.

Selve begrebet lederskab er mangetydigt - forskningen kalder det et 'omstridt' begreb - og på dansk er det om muligt endnu mere mangetydigt. Her siger vi typisk 'ledelse', mens vi på engelsk bruger to begreber, nemlig 'leadership' og 'management'. I denne distinktion vil leadership ofte henvise til at skabe 'indflydelse' i forhold til nye og komplekse spørgsmål, mens management modsat henviser til anvendelse af eksisterende 'procedurer' på kendte spørgsmål (Grint, 2005b). Den britiske ledelsesforsker Keith Grint skelner også imellem fire principielt forskellige forståelser af begrebet leadership: Det kan opfattes som noget, der handler om en person, en position, en proces eller et resultat (Grint, 2005a). Hvis vi opfatter leadership på den førstnævnte måde; som noget, der handler om personen, så fokuserer vi typisk på personlige egenskaber som intelligens, personlighedstræk, evner, karisma mv. Denne opfattelse er den mest dominerende i litteraturen. Hvis vi derimod primært opfatter ledelse som omhandlende en position, tænker vi typisk på en overordnet rolle i et hierarki, hvor nogen har til opgave at styre og kontrollere det, andre - medarbejdere eller følgere - gør. Dette er den mest traditionelle, weberianske version af ledelsesteori, og den er let genkendelig for praktikere. Hvis vi så opfatter leadership som en proces, handler det typisk om, at nogen påvirker og øver indflydelse på nogle andre ved at designe og orkestrere samarbejdsprocesser og relationer. Og tænker vi endelig på det som resultat, henviser det til, når organisationen opnår eller producerer noget (som for eksempel det at vinde en fodboldkamp eller øge aktiekursen).

De fleste definitioner af leadership inkluderer idéer om påvirkning og indflydelse, og Grint selv mener ikke, at det giver mening at tale om leadership, uden at der findes følgere på en eller anden måde. Med andre ord: Ikke alt, som en person i positionen 'chef' gør, er leadership. Det er kun leadership, når der skabes følgeskab. For at etablere følgeskab kan dog såvel personen (evner, stil mv.) som positionen (den formelle rolle), processen (de måder, personerne interagerer på), og resultatet (det, der bliver skabt i samspillet) spille en rolle. Typisk handler det danske begreb 'ledelse' om noget, en 'leder' gør, og ligger dermed tæt på det, Grint taler om som et positionsperspektiv.

I denne tekst vil vi fokusere mindre på ledelse i betydningen 'at håndtere en chefrolle' og mere på det, der har at gøre med, at der bliver skabt leder-følger-relationer, og at der bliver skabt påvirkning og handling i organisationen. Vi går heller ikke ud fra, at den, der opfattes som 'leder', nødvendigvis har en formel position. Lederskab kan også opstå igennem, at nogen i en hierarkisk lavere position påvirker en person i en højere position, i en ligestillet position eller for den sags skyld helt uden for den aktuelle organisation. Dette sidste optræder for eksempel ofte i projekter, der involverer flere organisationer. 


\section{praktiske grunde såvel som spændende teoretiske ressourcer til at udvikle en mere relationel og kontekstuelt sensitiv forståelse af lederskab. Vi vil også argu- mentere for, at sådan en lederskabsforståelse er særlig relevant for offentlige organisationer, givet deres opgaver og kontekst.}

Selvom formelle positioner ofte er vigtige i offentlige organisationer, fordi de typisk er organiseret som bureaukratier, mener vi, at et relationelt procesperspektiv er meget relevant og hjælpsomt. I offentlig virksomhed navigerer man typisk i komplekse kontekster med stærk politisk styring, mange forskellige aktører, logikker, krav og forventninger. Her er der ofte brug for lederskabsprocesser, der involverer flere personer, går på tværs af organisatoriske grænser, og som kobler sig på flere forskellige logikker. Der er også brug for at navigere i og tage hensyn til de politiske og relationelle dimensioner, så at anerkendelse for organisationens resultater bliver placeret på en acceptabel måde for den politiske ledelse. Offentlige organisationer domineres typisk af stærke professioner, hvilket indebærer, at de fagprofessionelle er centrale for såvel strategiske som faglige beslutninger og tiltag. Det, der opfattes som handleretten, ligger ofte hos den fagprofessionelle snarere end i den formelle lederrolle.

Endvidere står den offentlige sektor over for store udfordringer, der kræver nytænkning, forandring og udvikling, der går udover såvel som udfordrer eksisterende strukturer og dermed en positionsbaseret ledelsestilgang. Linjen fra den politiske ledelse og ud til borgerkontakten er sjældent tilstrækkelig, når vi stilles over for aktuelle, samfundsmæssige udfordringer. Faktisk kan linjen netop skabe silotænkning og lokal snarere end global optimering. Den amerikanske lederskabsudvikler Ron Heifetz mener for eksempel, at lederskab indebærer, at man går ud over sin givne autoritet, for eksempel ud over sin formelle rolle i hierarkiet (Heifetz, Grashow \& Linsky, 2009).

Den særlige kontekst for offentlige organisationer spiller en væsentlig rolle for governance- og styringstanker. Her er det selve organisationslogikkerne, der er i fokus; ofte på et niveau, der omfatter hele eller store dele af organisationen, undertiden hele stater og verdensdele. Vi finder her begreber som Public Administration, New Public Management og New Public Governance Andersen, Greve \& Torfing, 2017). Det er mere uklart, hvordan sådanne logikker spiller ind i et lederskabsperspektiv. Mens styringslogikker typisk er ret abstrakte, finder vi lederskab på handleplanet, hvor det involverer konkrete individer, relationer og interaktioner. Man kan muligvis sige, at lederskab mere handler om, hvordan styring og ambitioner bliver til en virkelighed (eller ikke) end om styringslogikkerne i sig selv.

Men hvornår er det egentlig relevant at bruge et lederskabsperspektiv? Lad os se på et par cases og prøve at demonstrere værdien $i$ at anlægge ikke bare ét, men forskellige lederskabsperspektiver. Case 1 er fra en IT-implementeringsproces i en kommunal kontekst: 


\section{Case 1}

Nete er afdelingsleder i et kommunalt jobcenter med 120 medarbejdere fordelt på seks teams med hver sin teamkoordinator. I organisationen er der brug for et nyt IT-system, og Nete står overfor at starte implementeringen af dette. Samtidig meddeler kommunen, at der er behov for besparelser, hvilket konkret udmøntes i, at personalet skal reduceres med otte personer. Netes erfaring fra den tidligere implementering af det nuværende IT-system er, at der var meget modstand og utilfredshed blandt personalet, og hun frygter det samme for den nye implementering. Endvidere forestiller hun sig, at fyringsrunden kommer til at spille ind i implementeringen og skabe mere støj, utilfredshed og friktion i organisationen og tillige problemer i organisationens levering af service til borgerne. Hvordan kan Nete håndtere disse udfordringer?

Case 2 drejer sig om trivsel og arbejdsgange i centraladministrationen:

\section{Case 2}

Monica er kontorchef i et ministerium, der har gennemgået en omfattende organisationsforandring inden for de sidste par år med det formål at skabe en mere agil organisation og muliggøre flere uformelle samarbejdsrelationer. Samtidig er der et ønske fra departementschefen om stærk topledelse, hvor en koncerndirektør tager stilling til alle større opgaver og beslutninger. Man har for nylig gennemført en trivsels- og ledermåling med ret dårlige resultater for tilfredsheden med arbejdsgange. Monica står nu over for udfordringen at forbedre arbejdsgangene, og resultatet fra trivselsmålingen kan være et udgangspunkt for det arbejde. Hvordan kan hun gøre det bedst, når hun befinder sig i et krydspres mellem meget tydelig topstyring og udbredt utilfredshed blandt medarbejderne?

Lederskabsforskningen tilbyder en lang række forskellige perspektiver og begreber til at analysere denne type udfordringer. Hovedparten tager afsæt i en forestilling om lederskab som noget, der udøves af en person, oftest i en formel lederrolle og med fokus på, hvad denne person gør, eller hvem personen er. Vi kalder denne slags perspektiver 'ledercentriske' til forskel for perspektiver, der mere sætter fokus på relationer, interaktioner, eller hvordan lederskab er delt eller distribueret mellem flere personer.

Vi skal kort kigge på to traditioner som eksempler på ledercentrerede perspektiver: adfærdsteorier om lederskab og transformativt lederskab, hvorefter vi vil prøve at anvende dem på de to cases.

\section{Lederadfærd}

Interessen for lederens adfærd tager afsæt i observationen, at det er meget svært at finde ud af, hvad en effektiv leder er, dvs. hvilke egenskaber der er mere eller mindre effektive. Adfærdsforskningen kommer altså som en reaktion på en frustration med resultaterne af forskningen om personens træk, evner osv. Forhåbningen er, at det med stor sandsynlighed er vigtigere, hvad en leder gør, end hvem lederen er. 
Forskningen i lederadfærd påvirkedes fra starten meget af det arbejde, der blev udført ved Ohio State University i USA i 1950'erne (Fleishman, 1953). Her forsøgte man at finde relevante kategorier for lederadfærd og udvikle spørgeskemaer til at måle disse. Relativt tidligt fandt man to brede kategorier af adfærd, som siden da har figureret $\mathrm{i}$ mange andre studier. De to kategorier handler om opgaveorienteret adfærd og relationsorienteret adfærd.

Opgaveorienteret adfærd indebærer at udpege specifikke opgaver til enkeltpersoner, at sætte mål og succeskriterier, at forklare procedurer mv. Relationsorienteret adfærd indebærer i stedet et fokus på personer og disses indbyrdes relationer. Det kan handle om at udtrykke støtte eller tillid til konkrete personer, at engagere sig i samtaler for at bygge relationer op, at coache medarbejdere eller at håndtere konflikter.

Disse to dimensioner skal opfattes som uafhængige af hinanden. Det indebærer, at en leder kan gøre meget af begge, mest af den ene type eller lidt af begge. Der findes dog også andre dimensioner af lederadfærd. I en oversigtsartikel sammenfatter Gary Yukl forskningen i fire adfærdskategorier: opgaveorienteret, relationsorienteret, forandringsorienteret og eksternt orienteret (Yukl, 2012).

Bruger vi disse begreber på casen ovenfor, får vi øje på nogle nye ting. I case 1, hvor Nete skal implementere et IT-system i skyggen af besparelser, kan man argumentere for, at der er behov for en meget relationsorienteret adfærd af lederen grundet organisationens tidligere erfaringer med utilfredshed og modstand. Samtidig kan man argumentere for, at besparelser håndteres bedst med tydelighed og klarhed i den opgaveorienterede adfærd, så der ikke opstår tvivl om, hvad der skal ske, eller hvem der gør hvad i levering af service. Dilemmaet her kunne formuleres som at indebære en samtidig og høj relations- såvel som opgaveorientering. Herefter bliver spørgsmålet, hvordan man i praksis gør det, når implementeringen samtidig skaber uro, usikkerhed og utilfredshed blandt personalet.

I case 2, hvor Monica står i et krydspres mellem departementschefens forventninger og medarbejdernes frustrationer, er der behov for balance i den relationsorienterede adfærd, så personalets erfaringer og oplevelser bliver hørt på relevante måder. Samtidig betyder den stærke topstyring, at den relationsorienterede adfærd må kombineres med en opgaveorienteret adfærd, der skaber klarhed over, hvad der er topstyret, og hvad der kan besluttes i de mere agile teams. Man kan sige, at udfordringen og dilemmaet her lige præcis handler om, hvordan Monica balancerer, så der er tilpas, men ikke for meget, opgaveorientering, samtidig med at den relations-orienterede adfærd ikke kommer til at signalere ubegrænset beslutningskompetence i de agile teams.

Som de to cases illustrerer, er der forskellige faktorer, der påvirker, hvilken adfærd der er mest konstruktiv i en konkret situation. Det er svært at finde en one size fits all-kombination, og i stedet må vi her som så mange andre steder konstatere, at den gode lederadfærd afhænger af situationen.

For at tage højde for situationens krav til ledelsesadfærd udviklede ledelsesforskningen det, der kaldes kontingensteorier, dvs. teorier om, hvad den optimale adfærd er 
afhængig (dvs. kontingent) af, hvilket så betegnes kontingensfaktorer. Den største udfordring her er at identificere, hvilke faktorer i situationen der er de vigtigste. De to bedst kendte bud på dette er Fiedlers kontingensteori (1964) og Hersey og Blanchards såkaldte situationstilpassede ledelsesteori, SLT (1969). Fiedler foreslog, at det er en kombination af stress (hvor meget tid der er til opgaven), opgavens kompleksitet, og lederens legitimitet hos gruppen. Hersey og Blanchard foreslog, at det er gruppens 'modenhed', der er det vigtigste, dvs. gruppens parathed til at påtage sig sin opgave.

Denne type af tænkning giver ofte god mening, og især Hersey og Blanchards model er blevet meget populær. Senere forskningsmæssige resultater har dog haft svært ved at støtte kontingensmodellernes påstand om, hvad den mest effektive ledelsesadfærd er. Der er også andre problemer med den slags teorier. Modellerne går ud fra, at en leder blot kan vælge sin adfærd afhængigt af, hvilken situation hun står i, hvilket forudsætter en stor fleksibilitet hos disse ledere. Man kan sætte spørgsmålstegn ved, om dette altid er tilfældet, eller om en del ledere har et mere begrænset, vanemæssigt repertoire, herunder personligt foretrukne ledelsesstile.

\section{Transformativt lederskab}

Den adfærdsorienterede tilgang til lederskab kan siges være relativt analytisk og intellektuel i den forstand, at vi forestiller os en leder, der kan tilpasse sin adfærd til det, der er brug for. I 1970'erne opstår så en anden tilgang til lederskab, som i stedet tager sit udgangspunkt i vision og passion, nemlig karismatisk og transformativt lederskab (Bryman, 1992; Burns, 1978; Conger \& Kanungo, 1998).

Det transformative lederskab blev introduceret i 1970'erne af flere forskere. Burns' bog 'Transformational Leadership' (1978) fik stor betydning, og det gælder også Zalezniks skel imellem 'leadership' og 'management' (1977). Transformationelt lederskab blev et begreb for noget, der handler om at motivere følgere til ekstraordinære indsatser, til at kunne lede sig selv og træffe beslutninger, der sigter mod et vigtigt, fælles mål.

Forestillingen om en vision spiller en stor rolle her, det vil sige noget, som følgere forbinder sig med følelsesmæssigt. Den karismatiske eller transformationelle leder er også passioneret snarere end distanceret og analytisk.

Disse ledere '...transform their concern for followers' needs into total dedication and commitment to the common cause they share with followers in a disinterested and selfless manner' (Conger \& Kanungo, 1987, s. 642).

Begrebet karisma spiller en stor rolle inden for denne tænkning. Begrebet er bedst kendt fra sociologen Max Weber, der identificerer karisma som en af tre typer af autoriteter i lederskabet (Weber, 1958). De andre to typer af autoritet er traditionel autoritet, hvor ledelse baseres på historie og tradition, og legal autoritet, hvor ledelse baseres på lovgivning og rationalitet. En karismatisk leder er en person, der umiddelbart opleves som usædvanligt stærk eller charmerende og med en personlig evne til at tiltrække følgere. Weber understreger, at en karismatisk leder typisk opstår, når et samfund er i krise, når der findes en parathed til at søge nye veje, og når håbet om en ny 
løsning kan tilskrives en person, der skiller sig ud og kan pege på et svar. Karisma er for Weber således ikke kun et spørgsmål om individuelle, personlige egenskaber, men noget, der opstår i en særlig situation og i relationen mellem ledere og følgere, hvor en gruppe mennesker oplever en leder som karismatisk.

Karisma bliver et centralt element i formuleringen af en ledelsestænkning, hvor dette at motivere følgere til noget særligt står i centrum. Burns (1978) understreger, at lederskab ikke kun handler om at organisere arbejdet med eksisterende opgaver, men om at løfte en gruppe mennesker til et højere niveau, såvel motivationsmæssigt som moralsk. Følgere skal stimuleres til at engagere sig i noget, der er godt for fællesskabet, ikke kun godt for individet selv.

Det nye lederskabsparadigme indeholder flere forskellige definitioner af karismatisk og transformativ ledelse. Mest kendt og brugt er den måde, som Bass og Avolio (1990; Bass \& Riggio, 2006) udviklede teorien om transformationel ledelse på, med fire dimensioner i det transformationelle lederskab:

1. Påvirkning gennem vision og karisma ('idealized influence'): Lederen kommunikerer visionen for organisationen. Lederen er følelsesmæssigt engageret, og følgere kan identificere sig med lederen. Her tillægges karaktertræk som karisma hos lederen stor betydning for, om medarbejderne opfatter visionen som tiltrækkende, legitim og autentisk.

2. Inspirerende motivation ('inspirational motivation'): Lederen kommunikerer høje forventninger til medarbejdere og inspirerer dem til også at forvente meget af sig selv og derfor præstere mere.

3. Intellektuel stimulering ('intellectual stimulation'): Lederen støtter og opfordrer til kreativ og innovativ adfærd og nye løsninger.

4. Opmærksomhed på individer ('individual consideration'): Lederen skaber et støttende klima, hvor det enkelte individ bliver set og kan udvikle sig til at blive den bedste version af sig selv ud fra sit potentiale.

I lighed med de tidligere adfærdsteorier beskrives her primært lederens handlinger. En central forskel i forhold til de tidligere teorier er, at fokus i teorier om det transformationelle lederskab ligger på følelsesmæssigt engagement, motivation og identifikation med lederen eller organisationen. Perspektivet overskrider dermed de tidligere adfærdsteoriers forudsætninger og skaber en ny grundlæggende forståelse for ledelsesrelationen, dvs. for relationen mellem leder og medarbejder.

\section{Medarbejderne ses ikke længere kun som individer, der alene er interesserede i sig selv, men som mennesker med et behov for en større mening med deres arbejde og et behov for at arbejde mod et fælles, værdibaseret mål.}

Hvis vi atter betragter case 1, hvor Netes afdeling stod over for både IT-implementering og fyringsrunde, kunne transformativ ledelse stille for eksempel disse to spørgsmål ud fra dimensionerne i transformativt lederskab ovenfor: Hvordan kan Nete formulere og kommunikere visionen med IT-implementering tilstrækkeligt karismatisk til, at hendes ledere og medarbejdere følelsesmæssigt vil identificere sig med hende og visionen om et nyt IT-system i en organisation, der vil have færre medarbejdere? Dette 
er en vanskelig opgave, blandt andet fordi det skal ske i en kontekst, hvor den forrige IT-implementering er i frisk erindring. Men også fordi alt for meget patos omkring forandringer kan udløse skepsis og yderligere modstand i en dansk virksomhedskultur. Videre spørger transformativt lederskab, hvordan Nete (og hendes gruppe af ledere) kan vise den enkelte medarbejder opmærksomhed i processen? Det kunne måske her oversættes til samtaler og outplacement-programmer og andre former for støtte til de opsagte.

I case 2 skal Monica forbedre arbejdsgangene i et krydspres mellem meget tydelig topstyring og udbredt utilfredshed blandt medarbejderne. Her kunne man vende sig mod dimensionen intellektuel stimulation: I modsætning til tidligere inddrager moderne arbejdsgangsanalyse og forbedring medarbejderne i både kortlægning, implementering og vedligeholdelse. Monica kunne forsøge at designe projektet sådan, at medarbejderne oplevede, at der var brug for deres kreative og innovative ressourcer. I det arbejde kunne hun jo kommunikere høje forventninger til både sig selv og sine medarbejdere, jævnfør dimension 2 i transformativt lederskab. Her er Monica ude i en delikat balancegang, når medarbejderne allerede er utilfredse.

\section{Hvorfor er ledercentrering problematisk - og hvorfor særligt i den offentlige sektor?}

Teorierne om transformativt lederskab har været meget indflydelsesrige inden for lederskabsforskningen. Ikke mindst baseret på at det er lykkedes forskere at udvikle et populært instrument til at måle transformationelt lederskab (MLQ, Multifactor Leadership Questionnaire; Bass \& Avolio, 1990), har dette perspektiv i lang tid været relativt dominerende i lederskabsforskningen. Perspektivet bidrager med noget i forståelsen af, såvel hvordan handlinger kan organiseres (gennem forskellige slags adfærd), som hvordan følgeskab kan mobiliseres (igennem inspirerende motivation etc.). Den største del af forskningen har dog fundet sted i private virksomheder eller i militæret. Den fokusering på lederen, som ligger i perspektivet, stimulerer ofte en heroisering af ledere, som muligvis passer i en privat og måske mere entreprenant kontekst. Den passer dog lidt mindre i en offentlig kontekst med et traditionelt syn på ledere mere som embedsmænd og saglige end som passionerede og risikovillige.

Perspektivet har også mødt en del kritik, der i det sidste årti er vokset og har fået større indflydelse Antonakis, Bastardoz, Jacquart, \& Shamir, 2016; Judge \& Piccolo, 2004; van Knippenberg \& Sitkin, 2013). Vi skal her tage tre generelle begrænsninger og problemer med ledercentrerede teorier op.

For det første er udgangspunktet her den formelle leder, og derfor siger denne slags teorier mindre om, hvilken rolle andre (som for eksempel følgere) spiller i en lederskabsproces og om andre veje til mobilisering end gennem personlig karisma. Det betyder, at forskningen - og praksis - kan komme til at overvurdere den formelle leders betydning og tilsvarende overvurdere karisma som ressource i indflydelsesprocesser.

For det andet siger teorierne heller ikke så meget om, hvordan lederskab kan eksistere i en situation, hvor der ikke er et klart, positionsbåret lederskab som for eksempel i ligestillede relationer (for eksempel i projektgrupper) eller i situationer uden ledere som for eksempel i nogle former for folkelig opstand. 
For det tredje siger teorierne (også adfærdsteorierne) mindre om selve den proces, igennem hvilken lederskabet opstår, og påvirkning således etableres. Teorier om lederadfærd siger for eksempel ikke noget om, hvornår og hvorfor lederens opgaveorienterede adfærd efterkommes af følgerne og altså ikke ignoreres. Teorier om transformativt lederskab siger ikke så meget om, hvordan den følelsesmæssige kobling til lederen og visionen faktisk opstår. Fænomenet defineres så at sige af sin effekt, af mobiliseringen af følgere, og siger derfor mindre om selve den proces, hvor følgeren bliver til en følger. Processerne er altså i en 'black box', hvilket også får betydning for teoriens praktiske anvendelighed, idet det bliver uklart, hvilke processer organisationens medlemmer kan forsøge sig med for at styrke bestræbelsen på at skabe følgeskab.

\section{På vej til et relationelt og kontekstuelt perspektiv på lederskab}

Medier og hverdagsfortællinger om, hvad der sker i virksomheder og i politik, fokuserer ofte meget på ledere og disses personlige egenskaber og meritter. I 1980'erne blev Meindl og hans kolleger i Californien optaget af dette og designede en række eksperimenter (Meindl et al, 1985). Via disse demonstrerede de, at når vi til hverdag forklarer eller skaber mening i forandringer, så har vi en tendens til at bruge ordet 'leder' som en forklaringsmodel. Med andre ord er ordet 'leder' eller 'lederskab' brugbart, når vi skal prøve at forklare (for os selv og for andre), hvorfor et eller andet sker (eller ikke sker) i en organisation. Dette er et eksempel på det, som socialpsykologien kalder attribution eller tilskrivning, dvs. den måde, hvorpå vi i vores tænkning besvarer spørgsmålet 'hvorfor skete dette?'. Vi tilskriver eller attribuerer dermed årsager (uanset om de er 'rigtige' eller ej) til observationer. Dette gør vi for at håndtere den ekstremt komplekse sociale verden, hvor det er umuligt for os at forholde os til alting samtidigt. Lederskab og leder tilbyder sig som ressourcer for at 'forklare' forandring, så vi får en følelse af at have forstået, hvorfor noget fandt sted, uanset at de virkelige årsager kan være nogle helt andre og mere komplekse.

Meindl og hans kolleger kaldte det fænomen, at vi overvurderer betydningen af ledere i en kompleks organisatorisk verden, for romantiseringen af lederskab ('the romance of leadership'). Til trods for, at denne idé om enkeltpersoners betydning er meget urealistisk, peger de på, at den kan have meget konstruktive og for så vidt positive konsekvenser. Vi kan til og med forestille os følgeskab, skabt alene på baggrund af tilskrivningen af lederskab. Denne proces starter med, at vi attribuerer lederskab til nogen eller noget. Når vi har gjort det, tenderer vi til i fællesskabet at forstærke det - altså at gruppeprocesser og andre sociale processer understøtter det. Når vi så har attribueret lederskab til nogen, tenderer vi til at handle som 'følgere'. Dermed kan vi skabe 'lederskabseffekter' helt uden, at der er nogen ledere involveret. Denne proces er efterfølgende demonstreret eksperimentelt (Weber, Camerer, Rottenstreich, \& Knez, 2001).

Mens den største del af forskningen såvel som hverdagsforståelsen opfatter lederskab som noget, der påvirker noget andet, altså som eksisterer før en handling eller bevægelse, kan vi her opfatte det omvendt. Når lederskab forstås som noget, følgere bruger til at forklare noget, der allerede er sket, så 'sker' lederskabet jo efter dette. 
Efterfølgende kan følgere så organisere sig og bruge lederskab som en forklaring på og begrundelse af den organisering. På den måde kan vi så udfordre hverdagsforestillingen om, at det er lederskab, der skaber bevægelse, og i stedet sige, at bevægelse kan skabe en oplevelse og erfaring af lederskab gennem tilskrivelse.

Den nyere lederskabsforskning tager i stor udstrækning afsæt i disse og lignende spørgsmål, og det er det, vi nu vil fokusere på. I løbet af de sidste cirka 20 år optræder der inden for lederskabsforskningen flere interessante bevægelser, men det, vi vil lægge mest vægt på her, er den stigende interesse for lederskab som delt og distribueret, som en relationel proces, og som noget, der er situeret i og konstitueret af en specifik kontekst. Der findes også en række andre spændende udviklingslinjer som kognitivt orienteret forskning, identitetsperspektiv på lederskab, autentisk lederskab osv., men vi inddrager i det følgende kun disse felter i begrænset omfang.

\section{Shared leadership}

Begrebet delt lederskab ('shared leadership') er blevet beskrevet som et såkaldt 'threshold concept' (Meyer \& Land, 2005), det vil sige et begreb, der gør tydelig forskel, et før og et efter, på, hvordan vi kan tænke om og teoretisere lederskab. Tanken om delt lederskab er ikke ny, men har eksisteret i flere årtier. Den oplevede dog fornyet interesse i slutningen af 90'erne, blandt andet fordi teams blev en mere almindelig organiseringsform. Begrebet delt lederskab ('shared leadership') defineres i en indflydelsesrig bog af Pearce og Conger (2003) sådan her:

We define shared leadership as a dynamic, interactive influence process among individuals in groups for which the objective is to lead one another to the achievement of group or organizational goals or both. This influence process often involves peer, or lateral, influence and at other times involve upward or downward hierarchical influence. The key distinction between shared leadership and traditional models of leadership is that the influence process involves more than just downward influence on subordinates by an appointed or elected leader (see Pearce \& Sims, 2000, 2002). Rather, leadership is broadly distributed among a set of individuals instead of centralized in hands of a single individual who acts in the role of a superior. (s. 1)

Der er nogle ting i denne definition, som vi vil vise særlig opmærksomhed. For det første understreger citatet, at lederskab er en proces, ikke en person eller en position. Det er en proces, der handler om indflydelse eller påvirkning. For det andet, at det involverer flere personer. Det forudsættes ikke, at der er nogen, der er 'over' en anden, men vi forstår altså en proces, der kan ske i forskellige retninger i organisationen (eller ud over den), og som kan forandre sig over tid.

Denis, Langley og Sergi (2012) sammenfatter forskningen om shared leadership og identificerer fire forskellige betydninger af begrebet, som det er blevet brugt i litteraturen indtil 2012. Den første betydning er, at lederskab deles i toppen af en organisation, hvor to eller flere ledere sammen leder resten af organisationen. Her taler vi derfor om en position som leder, men hvor der findes mere end én person på denne position. Dette er noget, der praktiseres i mange offentlige organisationer, hvor der findes et formelt ledelsesmakkerpar med fælles ansvar for en afdeling, et afsnit (på et sygehus) 
eller et team. Den anden betydning er, at lederskab fordeles i hele organisationen, så personer på mange forskellige niveauer kan udøve lederskab. Lederskab er her delt i den forstand, at det ikke samles på et 'sted', men kan udøves af alle i organisationen. Disse to betydninger er i en vis forstand mere et spørgsmål om, hvem der udøver lederskab, og fra hvilke positioner, end om at det skulle være en proces. Derimod handler de sidste to betydninger mere om lederskab som proces. Den tredje betydning handler om et team, og at vi her kan forestille os lederskabsrollen rotere mellem teamets medlemmer eller udøvet i fællesskab mellem to eller flere i teamet. Her snakker vi altså om lederskab på samme niveau. Den fjerde betydning, som Denis et al. peger på, er at opfatte lederskab som en proces, hvor der er flere involveret. Denne betydning siger altså ikke noget om positioner eller hvilken kontekst, det foregår i.

\section{Delt lederskab er således et begreb, der går udover og udfordrer den klassiske mere weberianske forestilling om formel og positionsbundet autoritet. Mens et vigtigt princip i et bureaukrati er præcist at kunne udpege den enkelte rolles eller persons ansvar, handler delt lederskab om at gøre tingene i fællesskab i en eller anden forstand.}

Delt lederskab er også noget, som vi ofte finder i praksis, men ikke i organisationens formelle beskrivelser, hvilket også bidrager til delvist at usynliggøre det (Fletcher, 2004).

Der findes dog relativt få empiriske studier af delt lederskab. Til dels hører dette sammen med den dominerende spørgeskemametode inden for lederskabsforskning, hvor man typisk bruger en formel stilling som chef som udgangspunkt for at studere leadership. Dette bliver så sværere i en situation, hvor lederskab ikke nødvendigvis er baseret på formelle positioner. Derimod er det nemmere at studere med kvalitative metoder. For eksempel har Holm og Fairhurst (2018) studeret udvikling af delt lederskab i en kommune i Danmark, og især hvordan delt lederskab spiller sammen med hierarkisk, vertikalt lederskab. De noterer, at det hierarkiske lederskab kan opretholde former og strukturer, inden for hvilke det delte lederskab kan udvikles. For eksempel åbnes og lukkes møder ved hjælp af hierarkiske positioner, men på mødet kan lederskab blive mere flydende og forhandlet. De påpeger også, at det hierarkiske lederskab til tider kan være befriende i forhold til den mere tidskrævende forhandling, som det delte lederskab typisk indebærer.

Hvis vi bruger dette perspektiv for at kigge på vores to cases, så rejser dette perspektiv umiddelbart det samme spørgsmål i begge cases: Hvilke andre personer end de formelle ledere findes og har potentielt indflydelse på eller burde få indflydelse på, hvad der sker? I case 1 kan vi forestille os, at de seks teamkoordinatorer er vigtige at inddrage og dele ledelse med i implementeringen af det nye IT-system. En del af udfordringen kan så forstås i termer om, hvor meget den formelle leder kan tillade, at denne gruppe kan overtage ansvar for processen, og hvilke grænser der er for dette gruppeansvar.

I case 2 findes der en organisation med på den ene side teams, der med en agil arbejdsproces er nødt til at have et delt lederskab, og på den anden side en topstyring, der sigter mod kontrol og effektivitet. Det er nemt at forestille sig, at de dårlige resultater i trivselsmålingen har baggrund i, hvordan spændingen imellem disse to ledelsesparadigmer håndteres. Trivselsmålingen giver nu en mulighed for at ansvarliggøre 
teammedlemmerne i arbejdet med trivslen, for eksempel ved at lade lederskabet blive delt i teamet. Et vigtigt spørgsmål er så, hvordan den formelle leder kan håndtere denne balance, der nu ikke er imellem opgaveorienteret og relationsorienteret adfærd, men imellem at dele kontrol og autoritet på den ene side og tilbageholde kontrol og sørge for topstyring på den anden. Man kan forestille sig, at det er nemmere at håndtere, hvis den formelle leder ikke er alene, men at det formelle lederskab faktisk deles med en anden person (Wadel, 2012.

\section{Lederskab som interaktioner og relationer}

Et relationelt perspektiv på lederskab er som sådan ikke nyt. Den mest kendte teoriretning her er LMX, der siden 1970'erne har forsøgt at konceptualisere og undersøge lederskab som dyadiske, altså tosidige, relationer mellem en leder og en følger (Graen \& Uhl-Bien, 1995). Til trods for, at der i mange tilfælde findes en gruppe, der har samme leder (dvs. her snakker vi om lederen som en formel leder, altså et positionsbegreb om ledelse), fandt man, at der var stor forskel på, hvordan enkelte individer opfattede deres relation til lederen. Relationerne er italesat i termer af kvaliteten af denne, fra lav til høj. I en relation med lav kvalitet, en lav LMX-relation, sker der en udveksling af indsatser fra følgeren den ene vej og belønninger i form af løn eller anerkendelse fra lederen den anden vej. I en relation med høj LMX-kvalitet er der flere følelser på spil. Lederen og følgerne har tillid til hinanden, der skabes mening, og der udvikles gensidige forpligtelser.

Mere grundlæggende argumenterer såvel Uhl-Bien (2006) som Cunliffe og Eriksen (2011) for ikke at opfatte lederskab som en udveksling imellem to aktører, men som noget, der ontologisk hører hjemme i selve relationen. Uhl-Bien skelner imellem et entitativt relationsperspektiv, hvor man interesserer sig for to (eller flere) entiteter der interagerer. Her er så at sige selve aktørerne - lederen og følgeren - primære, de findes før relationen, og mainstream LMX-forskning baserer sig på denne ontologi. Et mere radikalt relationelt perspektiv sætter i stedet selve relationen som det ontologisk primære. Det vil sige, at forestillingen om og identiteterne af 'en leder' og 'en følger' bliver skabt $\mathrm{i}$ interaktionerne i denne relation, hvis de overhovedet bliver skabt.

Et forsøg på at studere lederskab som noget, der så at sige ligger mellem individer, er, når man analyserer optagelser af samspil og interaktion på arbejdet (Larsson, 2017). Her studerer man for eksempel, hvordan lederskab i betydningen påvirkning af et møde bliver udøvet gennem sammenfatninger (Clifton, 2006), eller hvordan handlinger organiseres igennem en forhandling af gensidige forpligtelser i forhold til en konkret opgave (Larsson \& Lundholm, 2013).

\section{Udviklingen af relationel lederskabsteori såvel som studier af lederskab i interaktioner bidrager til at flytte fokus fra en person (eller fra at en person, lederen, påvirker en anden person, følgeren) til det, der foregår imellem per- soner.}

En implikation af et sådant perspektiv er, at når det handler om at forsøge at forstå lederskab som en påvirknings- og indflydelsesproces, giver det mindre mening at tænke, at der allerede findes en leder og en følger, og at lederskab som påvirkning består 
i, at lederen påvirker følgeren. I stedet bør vi opfatte positionerne (eller rollerne eller identiteterne) leder og følger som noget, der bliver skabt i relationen, så at de så at sige opstår fra relationen. Det vil sige, at vi kigger på sociale processer, der skridt for skridt og samtale for samtale skaber og privilegerer nogle forståelser af lederskab over andre. Og at alle organisationens medlemmer kan deltage i disse, der samlet set skaber ikke bare koordination i organisationen, men også forandring; nye værdier, tilgange og måder at tænke på.

Hvis vi en sidste gang kigger på Nete og hendes IT-implementering, peger relationel ledelse på, at organisationen og ledelse-følger-relationerne måske slet ikke er så fastlåste i tidligere konflikter og følelsesmønstre, som traditionel organisationsteori ville antage. Nete skal måske ikke bære sine egne negative erindringer og forventninger ind i samtalerne, men snarere orkestrere interaktioner præget af åbenhed og nysgerrighed for, hvilke nye positioner, relationer og forventninger der bliver muliggjort og realiseret i organisationens aktiviteter. Konkrete handlinger kunne måske indebære at arbejde med små delprojekter fordelt med omtanke i Netes organisation og med tilsvarende korte deadlines, hvor delprojekter (der jo også involverer relationelle processer) kunne skabe nye erfaringer for, hvad organisationen kan og i videre forstand er.

I Monicas tilfælde bliver man opmærksom på, om topledelsens forestillinger om stram topstyring faktisk er et organiserende princip i det konkrete arbejde, eller om det også her er muligt at iscenesætte processer, hvor medarbejdere oplever at blive 'gjort til ledere' i lokale interaktioner, for eksempel i arbejdet med arbejdsgange. Jo mindre hierarki og jo hurtigere feedbackloops mellem delprojekter og aftagerne af projekternes resultater, desto større sandsynlighed for, at medarbejderne kan skabe lederskab og følgeskab rundt omkring i Monicas organisation.

\section{Opsamling}

Denne gennemgang og præsentation af forskellige lederskabsteorier og deres anvendelse indebærer et argument for, at det ikke mindst i den offentlige sektor er hjælpsomt og konstruktivt at komme væk fra en alt for ledercentreret forståelse af lederskab. De nyere og mindre ledercentrerede teorier er bedre til at tage højde for den organisatoriske kompleksitet uden at ende på et abstraktionsniveau, hvor det enkelte individ eller den lokale ledelsespraksis forsvinder. De synliggør, at skabelse af indflydelse, bevægelse, organisering af handlinger og forandring ikke kun opstår ud fra et enkelt individ, men ud fra mange. Samtidig tilbyder de en række begreber, der potentielt er hjælpsomme, når det handler om at kunne se nye handlemuligheder, der lige så meget handler om at muliggøre, at andre involverer sig i beslutninger og processer som selv at være den, der får tingene til at ske. Samlet set tilbyder lederskabsfeltet en meget bred horisont af teoretiske tilgange, der, selvom de ikke udgør en sammenhængende helhed, hver for sig kan åbne for en dybere forståelse af det meget komplekse fænomen, som lederskab i en offentlig, organisatorisk kontekst repræsenterer. 


\section{Hvilken relevans har dette for praksis - hvordan 'bruges' teorier om lederskab?}

Megen management- og organisationsteori har en tendens til både at blive opfattet og anvendt som normativ. Med dette mener vi, at teorien bliver brugt (og til tider skabt) med henblik på at finde et 'svar på' eller en 'anvisning til', hvad man skal gøre i en kompleks og presset organisatorisk situation. Det gælder ikke mindst inden for forskning i lederskab.
Forestillingen om, at forskning og forskningskommunikation kan give svar og handleanvisninger, kommer ikke mindst til udtryk i en enorm mængde pop- ulærvidenskabelig litteratur, der handler om, hvordan man bliver en effektiv og dygtig leder. At dette ikke fungerer så enkelt, demonstreres vel af, at det lederskab, vi ser i dag, næppe er meget bedre end det, vi så før al denne litteratur.

Mange mere erfarne lederskabsforskere er i stedet mindre selvsikre, når det kommer til relationen mellem forskning og praksis. Generelt opfatter man forskningens opgave som at forsøge at forstå et fænomen, men ikke nødvendigvis dermed at vide mere om, hvordan man udfører den daglige praksis. Og da slet ikke mere end dem, der allerede arbejder der.

Hvis vi ikke kan bruge lederskabsforskning til at give direkte handleanvisninger, hvad kan vi så bruge den til? Et af de vigtige potentialer, der ligger i forskning, er muligheden for at stille mere grundlæggende og til tider mere provokative spørgsmål, end hvad der er plads og legitimitet til i praksis. Derfor kan forskningen bidrage med to meget specifikke ting:

For det første kan forskningen bidrage med nye og alternative perspektiver. Lederskabsteori og -forskning kan udvide vores forståelse af et meget komplekst fænomen ved at give plads til vinkler og dynamikker, som vi i vores hverdag ikke har tid, begreber eller simpelthen overskud til at fange. Samtidig kan der være vinkler og dynamikker, som kan have stor betydning, når vi reflekterer over dem og forsøger at forstå deres rolle i vores egen praksis.

For det andet kan forskningen udfordre vores hverdagsforståelse. En meget vigtig del af forskningen handler om, at vi alle sammen har forestillinger om lederskab, som påvirker os. Selvom disse forestillinger udfylder en funktion for os, er de typisk også begrænsende.

Måske er romantiseringen af lederskab det mest tydelige eksempel. Vi har alle sammen en tendens til at tro, at lederen er meget vigtig for alt det, der foregår i organisationen. 'Romance of leadership'-forskningen demonstrerer, hvordan dette ofte er en overvurdering og simplifikation af meget mere komplekse sammenhænge.

Andre teorier, som for eksempel teorier om delt lederskab og relationel lederskabsteori, peger på andre aspekter af produktionen af lederskab end den enkelte person. Den slags udfordringer af vores hverdagsforståelse kan åbne nye perspektiver og hjælpe 
os med at opfinde nye handleveje med større potentiale, end hvis vi kun følger vores oprindelige hverdagsforståelse.

Begge ovennævnte funktioner bygger på vores evne til dels at observere vores egen handling i praksis, og dels at reflektere over den (Cunliffe, 2016). Snarere end at forskning og teori giver os handleopskrifter lige til at tage ned fra hylden, giver den os potentielt værktøjer til at udfordre vores handlinger og vore måder at forstå det, der foregår, på og stimulerer os til at reflektere over, hvad vi kan gøre. Med Heifetz, Grashow og Linsky's (2009) begreb inviterer lederskabsforskningen os 'op på balkonen', hvorfra vi kan observere og tolke det, der foregår i hverdagen 'på dansegulvet'.

Let's dance. 


\section{Litteratur}

Andersen, L. B., Greve, C. \& Torfing, J. (2017). Offentlige Styringsparadigmer: Konkurrence og Sameksistens. København: DJØF Forlag.

Antonakis, J., Bastardoz, N., Jacquart, P., \& Shamir, B. (2016). Charisma: An illdefined and ill-measured gift. Annual Review of Organizational Psychology and Organizational Behavior, 3, 293-319.

https://doi.org/10.1146/annurev-orgpsych-041015-062305

Bass, B. M., \& Avolio, B. J. (1990). Transformational Leadership Development: Manual for the Multifactor Leadership Questionnaire. Consulting Psychologists Press.

Bass, B. M., \& Riggio, R. E. (2006). Transformational Leadership. Psychology Press. Bryman, A. (1992). Charisma and Leadership in Organizations. Sage Publications.

Burns, J. M. (1978). Leadership. New York: Harper \& Row.

Clifton, J. (2006). A conversation analytical approach to business communication: The case of leadership. Journal of Business Communication, 43(3), 202-219. https://doi.org/10.1177/0021943606288190

Conger, J. A., \& Kanungo, R. N. (1987). Toward a behavioral theory of charismatic leadership in organizational settings. Academy of Management Review, 12(4), 637-647.

Conger, J. A., \& Kanungo, R. N. (1998). Charismatic Leadership in Organizations. Thousand Oaks, CA: Sage. https://doi.org/10.5465/amr.1987.4306715

Cunliffe, A. L. (2016). Republication of "On Becoming a Critically Reflexive Practitioner". Journal of Management Education, 40(6), 747-768. https://doi.org/10.1177/1052562916674465

Cunliffe, A. L., \& Eriksen, M. (2011). Relational leadership. Human Relations, 64(11), 1425-1449. https://doi.org/10.1177/0018726711418388

Denis, J-L., Langley, A., \& Sergi, V. (2012). Leadership in the Plural. Academy of Management Annals, 6(1), 211-283. https://doi.org/10.5465/19416520.2012.667612

Fiedler, F. E. (1964). A contingency model of leadership effectiveness. In: Advances in Experimental Social Psychology, 1, 149-190. https://doi.org/10.1016/s0065-2601(08)60051-9

Fletcher, J. K. (2004). The paradox of postheroic leadership: An essay on gender, power, and transformational change. The leadership quarterly, 15(5), 647-661. https://doi.org/10.1016/j.leaqua.2004.07.004

Fleishman, E. A. (1953). The description of supervisory behavior. Journal of Applied Psychology 37(1): 1-6. https://doi.org/10.1037/h0056314 
Graen, G. B. \& Uhl-Bien, M. (1995). Relationship-based approach to leadership: Development of leader-member exchange (LMX) theory of leadership over 25 years: Applying a multi-level multi-domain perspective. The Leadership Quarterly, 6(2), 219-247. https://doi.org/10.1016/1048-9843(95)90036-5

Grint, K. (2005a). Leadership: Limits and Possibilities. New York: Palgrave Macmillan.

Grint, K. (2005b). Problems, problems, problems: The social construction of 'leadership'. Human Relations, 58(11), 1467-1494.

https://doi.org/10.1177/0018726705061314

Heifetz, R. A., Grashow, A., \& Linsky, M. (2009). The Practice of Adaptive Leadership: Tools and Tactics for Changing Your Organization and the World. Harvard Business School Publishing India Pvt. Limited. https://doi.org/10.1111/j.1744-6570.2009.01168_4.x

Hersey, P., \& Blanchard, K. H. (1969). Life cycle theory of leadership. Training \& Development Journal.

Holm, F., \& Fairhurst, G. T. (2018). Configuring shared and hierarchical leadership through authoring. Human Relations, 71(5), 692-721. https://doi.org/10.1177/0018726717720803

Judge, T. A., \& Piccolo, R. F. (2004). Transformational and Transactional Leadership: A Meta-Analytic Test of Their Relative Validity. Journal of Applied Psychology, 89(5), 755-768. https://doi.org/10.1037/0021-9010.89.5.755

Larsson, M. (2017). Leadership in interaction. In J. Storey, J. Hartley, J-I. Denis, et al. (Eds.), The Routledge Companion to Leadership (pp. 173-193). New York: Routledge.

Larsson, M., \& Lundholm, S. E. (2013). Talking work in a bank: A study of organizing properties of leadership in work interactions. Human Relations, 66(8), 1101-1129. https://doi.org/10.1177/0018726712465452

Meindl, J. R., Ehrlich, S. B., \& Dukerich, J. M. (1985). The Romance of Leadership. Administrative Science Quarterly, 30(1), 78-102. https://doi.org/10.2307/2392813

Meyer, J. H., \& Land, R. (2005). Threshold concepts and troublesome knowledge (2): Epistemological considerations and a conceptual framework for teaching and learning. Higher education, 49(3), 373-388. https://doi.org/10.1007/s10734-004-6779-5

Pearce, C. L., \& Conger, J. A. (Eds.). (2003). Shared Leadership: Reframing the Hows and Whys of Leadership. Thousand Oaks: Sage.

https://doi.org/10.4135/9781452229539.n14

Uhl-Bien, M. (2006). Relational leadership theory: Exploring the social processes of leadership and organizing. The leadership quarterly, 17(6), 654-676. https://doi.org/10.1016/j.leaqua.2006.10.007

van Knippenberg, D., \& Sitkin, S. B. (2013). A Critical Assessment of CharismaticTransformational Leadership Research: Back to the Drawing Board? The Academy of Management Annals, 7(1), 1-60. https://doi.org/10.1080/19416520.2013.759433 
Wadel, C. C. (2012). Ledelse i et interaksjonsperspektiv. Sosiologi i Dag, 42(2).

Weber, M. (1958). The three types of legitimate rule. Berkeley Publications in Society and Institutions, 4(1), 1-11.

Weber, R., Camerer, C., Rottenstreich, Y., \& Knez, M. (2001). The Illusion of Leader ship: Misattribution of Cause in Coordination Games. Organization Science, 12(5), 582-598. https://doi.org/10.1287/orsc.12.5.582.10090

Yukl, G. (2012). Effective Leadership Behavior: What We Know and What Questions Need More Attention. Academy of Management Perspectives, 26(4), 66-85.

https://doi.org/10.5465/amp.2012.0088

Zaleznik, A. (1977). Managers and leaders: Are they different? Harvard Business Review, 15(3), 67-84. 